\title{
Lactobacillus mucosae sp. nov., a new species with in vitro mucus-binding activity isolated from pig intestine
}

\author{
Stefan Roos, ${ }^{1}$ Fredrik Karner, ${ }^{1}$ Lars Axelsson ${ }^{2}$ and Hans Jonsson ${ }^{1}$
}

\footnotetext{
1 Department of Microbiology, Swedish University of Agricultural Sciences, Box 7025, SE-75007 Uppsala, Sweden

2 MATFORSK, Norwegian Food Research Institute, Osloveien 1, N-1430 Ås, Norway
}

\author{
Author for correspondence: Hans Jonsson. Tel: +4618 673382. Fax: +4618673392. \\ e-mail: hans.jonsson@mikrob.slu.se
}

\begin{abstract}
A new Lactobacillus species from pig small intestine has been identified. In an attempt to isolate Lactobacillus reuteri strains carrying the putative colonization-factor gene (mub, for mucus binding) a mub-derived gene probe was used to screen pig intestinal material. A number of isolates were obtained and primary characterization showed that they were Gram-positive, catalasenegative, non-spore-forming, non-motile rods. Growth occurred at $45^{\circ} \mathrm{C}$ but not at $15^{\circ} \mathrm{C}$ and the DNA G+C content was $46 \mathrm{~mol} \%$. Cell wall analysis together with DNA-DNA hybridization and analysis of the 165 rRNA sequence revealed that the new isolates represent a previously undescribed Lactobacillus species closely related to $L$. reuteri, Lactobacillus fermentum and Lactobacillus pontis. The name Lactobacillus mucosae is proposed for this species and the type strain is $\mathrm{S}^{3} 2^{\mathrm{T}}$.
\end{abstract}

Keywords: Lactobacillus mucosae, new species, mucus binding

\section{INTRODUCTION}

The use of lactic acid bacteria $(\mathrm{LAB})$ in the production and preservation of food and animal feed dates back several thousand years. Today this use is manifested by various dairy products such as cheese and yoghurt, fermented sausages, vegetables and silage for animal feed. Recently, a great deal of interest has been focused on some members of the LAB with regard to their use as probiotics (Fuller, 1989; Marteau \& Rambaud, 1993; Salminen et al., 1996). The term 'probiotic' refers to live organisms that are administered to animals or humans via feed or food products and are in some way beneficial to health (Fuller, 1989). The LAB that are currently used as probiotics are primarily species of Lactobacillus and Bifidobacterium. In this context, bifidobacteria are often included in the LAB group since they have many features in common with this group. However, in contrast to the LAB group in general, bifidobacteria belong to the high $\mathrm{G}+\mathrm{C}$ group of Gram-positive bacteria. The positive effects attributed to these probiotic organisms include stabilization of the normal microflora, protection against pathogens, lowering of cholesterol levels,

Abbreviations: LAB, lactic acid bacteria; RDP, Ribosomal Database Project.

The GenBank/EMBL/DDBJ accession number for the 165 rDNA gene sequence of strain $\mathrm{S} 32^{\top}$ is $\mathrm{AF} 126738$. immune stimulation and protection against certain forms of cancer (Elmer et al., 1996; Isolauri et al., 1998; Lichtenstein \& Goldin, 1998). One of the basic assumptions regarding the important features of probiotic micro-organisms is the need for colonization ability (Huis in't Veld et al., 1994; Brassart \& Schiffrin, 1997). In contrast to the case of many pathogenic bacteria, little is known about the mechanisms by which LAB interact with host components in the intestinal tract. However, in recent years several reports have begun to establish a knowledge base on how lactobacilli adhere to the intestinal mucosa (Adlerberth et al., 1996; Roos et al., 1996; Yamamoto et al., 1996; Granato et al., 1999).

We have recently cloned and sequenced an extremely large gene, $m u b$, from the pig intestinal isolate Lactobacillus reuteri strain 1063, encoding a cell-surface protein with mucus-binding activity (S. Roos \& H. Jonsson, unpublished results). This protein, termed Mub, has a molecular mass of $358 \mathrm{kDa}$ and contains two types of large amino acid repeats. The parental strain, 1063, has very good binding activity against crude pig mucus in vitro. Furthermore, both the native and the recombinant $\mathrm{Mub}$ protein were shown to interact with immobilized mucus material. In order to clarify the correlation between the presence of $m u b$ and the ability to adhere to mucus material, we screened pig small-intestinal mucosa for bacteria harbouring 
this gene. In this work we describe the isolation of a number of strains that are reactive with a gene probe derived from mub and that exhibit binding to mucus material in vitro. Further characterization of these isolates showed that they represent a new Lactobacillus species that is closely related to L. reuteri, Lactobacillus fermentum and Lactobacillus pontis. Interestingly, three strains of lactobacilli previously isolated from pig small intestine (Axelsson \& Lindgren, 1987; Wadström et al., 1987) were shown to belong to this new species. These isolates also harbour mub and possess the ability to adhere to pig mucus in vitro. An oligonucleotide probe that can be used for rapid identification of Lactobacillus mucosae sp. nov. is also described.

\section{METHODS}

Origin of the strains. Strains 1028, 1031 and 1035 were isolated from pig small intestine and described earlier (Axelsson \& Lindgren, 1987; Wadström et al., 1987). Strains $\mathrm{S} 5, \mathrm{~S} 14, \mathrm{~S} 15, \mathrm{~S} 17$ and S32 ${ }^{\mathrm{T}}$ were isolated in this work. Small intestine from a newly slaughtered pig was collected from the slaughterhouse. In the laboratory, the intestine was sectioned and $15-\mathrm{cm}-$ long sections were cut open and rinsed with ice-cold PBS ( $8.0 \mathrm{~g} \mathrm{NaCl}, 0.2 \mathrm{~g} \mathrm{KCl}, 1.44 \mathrm{~g} \mathrm{Na}_{2} \mathrm{HPO}_{4} .2$

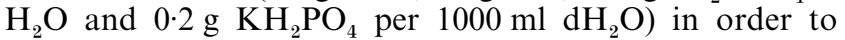
remove loosely associated intestinal material. Mucosal material was then released by gently scraping the intestine with a spatula. The released material was collected in a tube with ice-cold PBS and subsequently diluted and used to inoculate agar plates. L. reuteri DSM $20016^{\mathrm{T}}$, L. fermentum DSM $20052^{\mathrm{T}}$ and L. pontis DSM $8475^{\mathrm{T}}$ were obtained from the Deutsche Sammlung von Mikroorganismen und Zellkulturen (DSMZ), Braunschweig, Germany, and Lactobacillus acidophilus ATCC $4356^{\mathrm{T}}$ was obtained from the American Type Culture Collection (ATCC), Manassas, VA, USA.

Culture conditions. Primary isolation was done on Lactobacillus Selective Agar (BBL) in anaerobic jars under a $\mathrm{CO}_{2}+\mathrm{N}_{2}$ atmosphere (GasPak System, BBL) at $37^{\circ} \mathrm{C}$. All further cultivation was done at $37^{\circ} \mathrm{C}$ on De ManRogosa-Sharpe (MRS) agar (Oxoid), in anaerobic jars or in MRS broth (Oxoid) unless stated otherwise.

Morphological characteristics. Cell morphology was observed using phase-contrast microscopy. Gram determination was performed using both Gram-staining and the $\mathrm{KOH}$ method of Gregersen (1978).

Physiological and chemical characterization. Sugar-fermentation patterns were determined using the API $50 \mathrm{CH}$ system (BioMérieux). Cell wall analysis was performed at DSMZ. The preparation of cell walls and the determination of peptidoglycan structure were carried out using the methods described by Schleifer \& Kandler (1972), with the modification that TLC was performed on cellulose sheets instead of paper. The lactic acid configuration was determined using a commercial test kit (Boehringer Mannheim). Arginine cleavage was determined using the method of Collins \& Lyne (1970). Catalase activity was determined by transferring fresh colonies from MRS agar to a glass slide and adding $5 \% \mathrm{H}_{2} \mathrm{O}_{2}$.

DNA base composition. The $\mathrm{G}+\mathrm{C}$ content of the DNA $(\mathrm{mol} \%)$ was determined at DSMZ. The DNA was isolated by chromatography on hydroxyapatite using the procedure of Cashion et al. (1977). The G $+\mathrm{C}$ content of the DNA was determined using HPLC, as described by Mesbah et al. (1989).

DNA-DNA hybridization. DNA-DNA hybridization was performed at DSMZ, Braunschweig, Germany. DNA hybridization was carried out according to De Ley et al. (1970) with modifications as described by Escara \& Hutton (1980) and $\mathrm{Huß}$ et al. (1983), using a Gilford System 2600 spectrophotometer equipped with a Gilford 2527-R thermoprogrammer and plotter. Renaturation rates were calculated by the program TRANSFER: BAS (Jahnke, 1992).

Colony hybridization. The original isolates were recultivated and single colonies were inoculated on Protran BA85 nitrocellulose filters (Schleicher \& Schuell) placed on top of MRS-agar plates and grown overnight in anaerobic jars at $37^{\circ} \mathrm{C}$. Colony hybridization was performed according to Sambrook et al. (1989) with a modified protocol for lysis of the cells which includes a prolonged incubation with SDS (30 $\mathrm{min})$. An internal $1100 \mathrm{bp}$ restriction fragment from the $m u b$ gene of L. reuteri strain 1063 (S. Roos \& H. Jonsson, unpublished results) was labelled with ${ }^{32} \mathrm{P}$, with the Multiprime DNA labelling system (Amersham), and used as a probe in the hybridizations.

Western blot analysis. Bacteria were grown for $48 \mathrm{~h}$ at $37^{\circ} \mathrm{C}$ in $100 \mathrm{ml}$ Lactobacillus Defined Medium II (Kotarski \& Savage, 1979) supplemented with $1 \%$ glucose instead of sucrose. The cells were sedimented by centrifugation and the growth medium was sterile-filtered through a $45 \mu \mathrm{m}$ filter and dialysed against $1 \mathrm{mM}$ EDTA overnight with several changes of buffer. The material was then lyophilized and

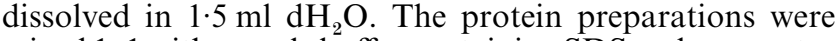
mixed $1: 1$ with sample buffer containing SDS and mercaptoethanol and separated by SDS-PAGE. The electrophoresis and staining of the gel with Coomassie blue was performed with the PhastSystem (Pharmacia Biotech) according to the manufacturer's instructions. The proteins were blotted to a Hybond-C nitrocellulose membrane (Amersham Life Science) by diffusion at $65{ }^{\circ} \mathrm{C}$ for $45 \mathrm{~min}$. The membrane was blocked in PBST (PBS supplemented with $0.05 \%$ Tween 20 , $\mathrm{pH} 7 \cdot 3$ ) for $1 \mathrm{~h}$ at $37^{\circ} \mathrm{C}$ and then incubated overnight at $4{ }^{\circ} \mathrm{C}$ with $10 \mu \mathrm{g} \mathrm{ml} l^{-1}$ antibodies against extracellular proteins from L. reuteri strain 1063 (S. Roos \& H. Jonsson, unpublished results) which had been preadsorbed with an Escherichia coli lysate according to Sambrook et al. (1989). After being washed with PBST, the membrane was incubated with HRP-conjugated goat anti-rabbit IgG (Bio-Rad), diluted $1: 1000$, at $37^{\circ} \mathrm{C}$ for $1 \mathrm{~h}$. After being washed, the membranes were finally developed with 4-chloro-1-naphthol as substrate.

Assay of mucus binding. Mucus was prepared from the same intestine that was used for isolation of bacteria. By scraping the inside of the intestine with a spatula, material was removed and collected in $200 \mathrm{ml}$ ice-cold PBS. The resulting suspension was centrifuged first at $11000 \mathrm{~g}$ for $10 \mathrm{~min}$ and then at $26000 \mathrm{~g}$ for $15 \mathrm{~min}$ in order to remove cells and particulate matter. The crude mucus preparation was stored at $20^{\circ} \mathrm{C}$. The mucus material was diluted to approximately $100 \mu \mathrm{g} \mathrm{ml}^{-1}$ in $50 \mathrm{mM} \mathrm{Na} \mathrm{CO}_{3}$ buffer, $\mathrm{pH} 9 \cdot 7$, and incubated overnight in microtiter wells (Greiner) (150 $\mu \mathrm{l}$ per well) at $4{ }^{\circ} \mathrm{C}$ with slow rotation. The wells were blocked with PBS with $1 \%$ Tween 20 for $1 \mathrm{~h}$ and thereafter washed with PBST. The bacteria were grown in MRS broth for $16 \mathrm{~h}$ at $37^{\circ} \mathrm{C}$, washed once in PBST and diluted to $\mathrm{OD}_{600}=0.5$ (1 cm cuvette; Beckman DU650) in the same buffer. Bacterial suspension $(150 \mu \mathrm{l})$ was added to each well and incubated for $1 \mathrm{~h}$ at room temperature. The wells were washed with PBST and binding was examined with an 
inverted microscope. The buffer was poured off and, after the wells had dried, the $\mathrm{OD}_{450}$ was measured in an ELISA plate reader (EL309 Autoreader; BIO-TEK Instruments).

16S rRNA gene sequencing. The almost complete $16 \mathrm{~S}$ rRNA gene was amplified by PCR by using slightly modified domain Bacteria-specific primers according to Weizenegger et al. (1992). The primer sequences were 5'-AGAGTTTGATYMTGGC-3' and '5'-AGAAAGGAGGTGATCC-3'. PCR reactions involved 35 cycles under the following conditions: $94^{\circ} \mathrm{C}$ for $30 \mathrm{~s}, 54^{\circ} \mathrm{C}$ for $30 \mathrm{~s}$ and $72{ }^{\circ} \mathrm{C}$ for $80 \mathrm{~s}$; the resulting PCR products were purified from agarose gels. Both strands of the purified fragments were sequenced using the Thermo Sequenase dye terminator cycle sequencing premix (Amersham) and the automated sequence analyser ABI PRISM 377XL (Perkin Elmer). The same primers that were used for the amplification were used (together with additional customized internal primers) to sequence the PCR products.

Phylogenetic analysis of the sequence data. The sequences achieved from the new isolates were used for searching in the public databases (GenBank and the Ribosomal Database Project, RDP). The sequences representing the best matches were retrieved and aligned using the CLUSTAL $\mathrm{W}$ program (Thompson et al., 1994). The sequences were manually modified before the alignment and approximately 1450 nucleotides covered by all sequences were used. The following sequences from the type strains of the respective species were used: L. fermentum, M58819; L. reuteri, X76328; L. pontis, X76329; Lactobacillus vaginalis, X61136; Lactobacillus oris, X94229; Lactobacillus panis, X94230; Lactobacillus sakei, M58829; Lactobacillus casei, X61135; Lactobacillus brevis, X61134; Lactobacillus salivarius subsp. salivarius, AF089108; Lactobacillus delbrueckii subsp. delbrueckii, M58814; Lactobacillus fructivorans, X76330; Pediococcus acidilactici, M58833. A distance matrix was calculated with the DNADIST program of the PHYLIP package (Felsenstein, 1993), using the Kimura 2-parameter model, and a phylogenetic tree was constructed with the NEIGHBOR program (PHYLIP package) using the neighbour-joining method. The statistical significance of the grouping was estimated by bootstrapping (100 replicates) using the programs SEQBOOT, DNADIST, NEIGHBOR and CONSENSE (all from the PHYLIP package).

Hybridization with a specific rDNA-targeted probe. Bacteria were grown and lysed on filters as described for the colony hybridization. The oligonucleotide LM16, with the sequence 5'-GTAAACCAACGTCAAGTCC-3', was designed to be specific for $16 \mathrm{~S}$ rRNA and $16 \mathrm{~S}$ rDNA from the new isolates by comparing sequences from different species. The PROBECHECK program at RDP was used to confirm the specificity of the probe. The customized oligonucleotide was labelled with ${ }^{32} \mathrm{P}$ using $\mathrm{T} 4$ polynucleotide kinase, according to Sambrook et al. (1989). The prehybridization, hybridization and washing were performed according to Sambrook et al. (1989). The temperature during hybridization and washing was $42^{\circ} \mathrm{C}$.

\section{RESULTS}

\section{Identification of colonies reactive with the mub probe, producing Mub protein and possessing mucus-binding activity}

In an attempt to isolate $L$. reuteri strains carrying the gene for the mucus-binding protein (Mub) (S. Roos \& H. Jonsson, unpublished results), we used a probe derived from this gene from L. reuteri strain 1063 for screening lactobacilli isolated from pig small-intestine mucosa. Approximately 100 colonies were screened with colony hybridization, of which five (S5, S14, S15, $\mathrm{S} 17$ and $\mathrm{S} 32^{\mathrm{T}}$ ) reacted with the probe. Fifty additional Lactobacillus strains previously isolated from pig small intestine [and characterized by Wadström et al. (1987) and Axelsson and Lindgren (1987)] were also screened with the probe: three of them (1028, 1031 and 1035) gave positive signals. Strains reacting with the probe were recultivated from the master plate and checked by SDS-PAGE and Western blotting for production of the mucus-binding protein, Mub. Since this protein is very large $(358 \mathrm{kDa})$, bands located at the top of the gel and reactive with antibodies against extracellular proteins from L. reuteri strain 1063 were considered to be Mub or a related protein. All strains that were reactive with the $m u b$ probe also produced a large protein reacting with the antibodies. The same set of strains was also positive in the assay of mucus binding (data not shown).

\section{Colony and cell morphology}

Colonies of strains S5, S14, S15, S17, S32 $2^{\mathrm{T}}, 1028,1031$ and 1035 were white, smooth and convex. After anaerobic growth for $2 \mathrm{~d}$ on MRS agar at $37^{\circ} \mathrm{C}$, the colonies were $1-2 \mathrm{~mm}$ in diameter. Cells of all strains were non-spore-forming, non-motile rods $1 \times 2-4 \mu \mathrm{m}$ in size. The Gram-reaction was positive.

\section{DNA base composition}

The mean $\mathrm{G}+\mathrm{C}$ content of strain $\mathrm{S} 32^{\mathrm{T}}$ DNA, based on three determinations, was $46.5 \pm 0.2 \mathrm{~mol} \%$. The $\mathrm{G}+\mathrm{C}$ content of strains 1028,1031 and 1035 was determined previously (Axelsson \& Lindgren (1987): the values for these three strains were 49,47 and $49 \mathrm{~mol} \%$, respectively.

\section{DNA-DNA hybridization}

On the basis of the 16S rRNA sequence analysis, three reference strains were chosen for DNA-DNA hybridization experiments with strain $\mathrm{S} 32^{\mathrm{T}}$. These were L. reuteri DSM $20016^{\mathrm{T}}$, L. fermentum DSM $20052^{\mathrm{T}}$ and L. pontis DSM $8475^{\mathrm{T}}$. The results showed homology values of $40.5,41.5$ and $52.2 \%$, respectively, between these strains and L. mucosae $\mathrm{S} 32^{\mathrm{T}}$.

\section{Physiological and chemical characterization}

Analysis of the cell wall of L. mucosae strain $\mathrm{S} 32^{\mathrm{T}}$ revealed the presence of ornithine and aspartic acid, which is consistent with an Orn-D-Asp peptidoglycan type. All strains grew well at $45^{\circ} \mathrm{C}$ but not at $15^{\circ} \mathrm{C}$. Gas was produced from glucose. All strains grew well in liquid and on solid MRS media in anaerobic jars. Weak growth also occurred on solid MRS media in the presence of air. Arginine was cleaved by all strains. Catalase activity was negative in all strains. D-Lactate and L-lactate were produced by all strains. The 
Table 1. Differential characteristics of Lactobacillus mucosae sp. nov. and closely related lactobacilli

ND, Not determined; $v$, variable reaction.

\begin{tabular}{|c|c|c|c|c|c|c|c|c|}
\hline \multirow[t]{2}{*}{ Strain } & \multicolumn{8}{|c|}{ Utilization of: } \\
\hline & $\begin{array}{l}\mathrm{NH}_{3} \text { from } \\
\text { arginine }\end{array}$ & $\begin{array}{l}\text { Growth at } \\
15 / 45^{\circ} \mathrm{C}\end{array}$ & $\begin{array}{c}\text { Gas from } \\
\text { glucose }\end{array}$ & Glucose & Ribose & L-Arabinose & D-Xylose & Galactose \\
\hline L. mucosae $\mathrm{S} 5$ & + & $-/+$ & + & + & + & + & + & + \\
\hline L. mucosae $\mathrm{S} 14$ & + & $-/+$ & + & + & + & - & - & - \\
\hline L. mucosae $\mathrm{S} 15$ & + & $-/+$ & + & + & $\mathrm{v}$ & - & + & - \\
\hline L. mucosae $\mathrm{S} 17$ & + & $-/+$ & + & + & + & - & + & + \\
\hline L. mucosae $\mathrm{S} 32^{\mathrm{T}}$ & + & $-/+$ & + & + & + & - & + & + \\
\hline L. mucosae 1028 & + & $-/+$ & + & + & + & + & + & + \\
\hline L. mucosae 1031 & + & $-/+$ & + & + & + & + & + & - \\
\hline L. mucosae 1035 & + & $-/+$ & + & + & + & + & + & - \\
\hline $\begin{array}{l}\text { L. reuteri DSM } \\
20016^{\mathrm{T}}\end{array}$ & + & $-/+$ & + & + & + & + & - & + \\
\hline $\begin{array}{l}\text { L. fermentum DSM } \\
20052^{\mathrm{T}}\end{array}$ & + & $-/+$ & + & + & + & - & - & + \\
\hline L. pontis DSM $8475^{\mathrm{T}} \uparrow$ & + & $+/+$ & - & - & + & - & - & - \\
\hline L. oris DSM $4864^{\mathrm{T}} \|$ & - & $-/+$ & + & +9 & + & + & + & $+\uparrow$ \\
\hline L. panis DSM $6035^{\mathrm{T}} \|$ & - & $-/+$ & + & + & + & + & + & ND \\
\hline $\begin{array}{l}\text { L. vaginalis DSM } \\
583^{\mathrm{T}} \|\end{array}$ & + & $-/+$ & + & $+\uparrow$ & - & - & - & +9 \\
\hline \multirow[t]{2}{*}{ Strain } & \multicolumn{6}{|c|}{ Utilization of: } & \multirow{2}{*}{$\begin{array}{c}\text { Peptidoglycan } \\
\text { type }\end{array}$} & \multirow{2}{*}{$\begin{array}{c}\mathrm{G}+\mathrm{C} \\
\text { content } \\
(\mathrm{mol} \%)\end{array}$} \\
\hline & D-Fructose & Aesculin & Lactose & Melibiose & D-Raffinose & Gluconate & & \\
\hline L. mucosae $\mathrm{S} 5$ & - & + & - & + & + & + & ND & ND \\
\hline L. mucosae $\mathrm{S} 14$ & - & + & - & - & - & - & ND & ND \\
\hline L. mucosae $\mathrm{S} 15$ & - & + & - & + & + & + & ND & ND \\
\hline L. mucosae $\mathrm{S} 17$ & - & + & - & + & + & + & ND & ND \\
\hline L. mucosae $\mathrm{S} 32^{\mathrm{T}}$ & - & + & - & + & + & + & Orn-D-Asp & $46 \cdot 5 \pm 0 \cdot 2$ \\
\hline L. mucosae 1028 & $\mathrm{v}$ & + & + & + & + & + & ND & $49 *$ \\
\hline L. mucosae 1031 & - & + & - & + & + & + & ND & $47 *$ \\
\hline L. mucosae 1035 & - & + & - & + & + & + & ND & $49 *$ \\
\hline $\begin{array}{l}\text { L. reuteri DSM } \\
20016^{\mathrm{T}}\end{array}$ & + & - & + & + & + & $+\$$ & Lys-D-Asp & $40-42 \div$ \\
\hline $\begin{array}{l}\text { L. fermentum DSM } \\
20052^{\mathrm{T}}\end{array}$ & + & + & + & + & + & + & Orn-D-Asp & $52-54 \ddagger$ \\
\hline L. pontis DSM $8475^{\mathrm{T}} \dagger$ & + & - & - & - & + & + & Orn-D-Asp & $53 \S$ \\
\hline L. oris DSM $4864^{\mathrm{T}} \|$ & + & + & + & + & + & + & Lys-D-Asp & $49-51 \#$ \\
\hline L. panis DSM $6035^{\mathrm{T}} \|$ & + & + & + & + & + & + & Lys-D-Asp & 48 \\
\hline $\begin{array}{l}\text { L. vaginalis DSM } \\
583^{\mathrm{T}} \|\end{array}$ & + & + & + & + & + & - & Orn-D-Asp & $38-41 * *$ \\
\hline
\end{tabular}

* Data from Axelsson \& Lindgren (1987).

$\dagger$ Data from Vogel et al. (1994).

\$Data from Kandler \& Weiss (1986). Data are typical for the species, not specifically the type strain.

$\S$ The values for L. pontis LTH 2585 and 2586 (Vogel et al., 1994).

\| Data from Wiese et al. (1996).

$\uparrow$ Data from Hammes et al. (1992).

\# Data from Farrow \& Collins (1988).

** Data from Embley et al. (1989). 


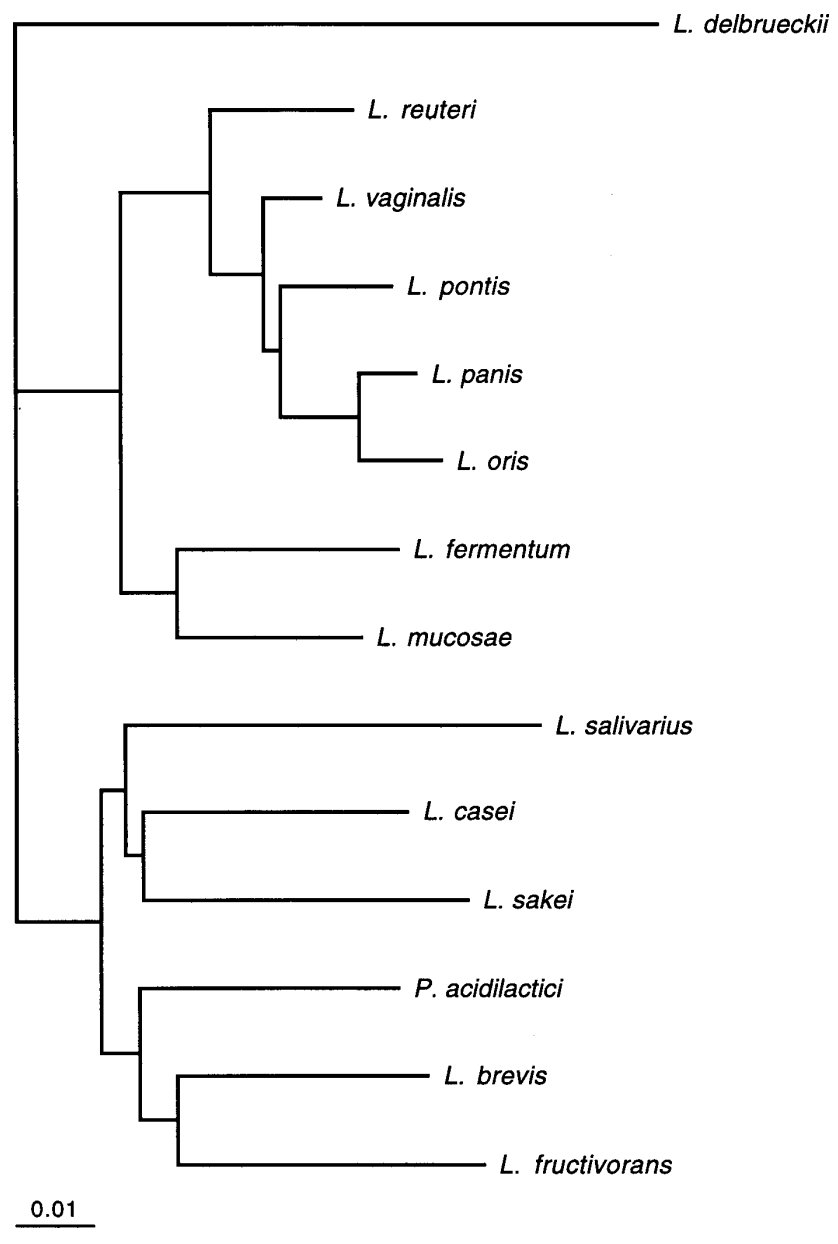

Fig. 1. Unrooted phylogenetic tree, derived from $16 \mathrm{~S}$ rRNA sequence analysis, showing the relationship between Lactobacillus mucosae strain $S 32^{\top}$ and members of the Lactobacillus casei-Pediococcus group of lactobacilli. The sequence from Lactobacillus delbrueckii was used as an outgroup representative. All strains are type strains. Approximately 1450 nucleotides from each sequence were used for the alignment. Bar, $1 \%$ estimated sequence divergence.

following sugars were fermented: glucose, ribose, maltose, saccharose, D-xylose (7 of 8 strains), melibiose (7 of 8), D-raffinose (7 of 8), gluconate (7 of 8), Larabinose (4 of 8), galactose (4 of 8) and lactose (1 of 8). There was no fermentation of D-fructose, glycerol, erythritol, L-xylose, adonitol, D-mannose, L-sorbose, rhamnose, dulcitol, inositol, mannitol, sorbitol, methyl $\alpha$-D-glucoside, $N$-acetylglucosamine, salicine, cellobiose, trehalose, inuline, melizitose, amidon, glycogen, xylitol, D-turanose, D-lyxose, D-tagatose, D-fucose, L-fucose, D-arabitol, 2-keto-gluconate or 5-ketogluconate. Aesculin was hydrolysed by all strains. The minor differences in the sugar-fermentation patterns of strains 1028, 1031 and 1035 found when data from this work were compared with data presented by Axelsson \& Lindgren (1987) cannot be explained at this point.
Relevant characteristics of the L. mucosae strains are summarized in Table 1.

\section{$16 S$ rRNA sequence and phylogenetic analysis}

Almost the complete 16S rDNA sequence was determined for strains $\mathrm{S} 14$ and $\mathrm{S} 32^{\mathrm{T}}$, while partial sequences from each end of the gene were determined for strains 1028, 1031, 1035, S5, S15 and S17. Analysis of all sequences from the 5'-and $3^{\prime}$ ends of the genes showed no differences except for a small number of ambiguities, so we concluded from these data that all isolates belong to the same species. The complete sequences from S14 and $\mathrm{S} 32^{\mathrm{T}}$ were aligned and found to be identical. The complete $\mathrm{S} 32^{\mathrm{T}}$ sequence was used to search the RDP and the highest similarity rank was found with $L$. reuteri, L. pontis and L. fermentum, the values being $95 \cdot 1,94.6$ and $94.4 \%$, respectively. The new sequence was then aligned with the sequences from members of the L. reuteri-L. fermentum branch of the L. casei-Pediococcus group and other representatives of this group and the alignment was used for a tree analysis. This analysis confirmed the close relationship of $L$. mucosae to $L$. reuteri and $L$. fermentum (Fig. 1).

\section{Specific detection of $L$. mucosae with the aid of a rDNA probe}

Colony hybridization of the oligonucleotide probe LM16 (5'-GTAAACCAACGTCAAGTCC-3') with all eight $L$. mucosae strains, $L$. reuteri DSM $20016^{\mathrm{T}}, L$. fermentum DSM $20052^{\mathrm{T}}$ and L. acidophilus ATCC $4356^{\mathrm{T}}$ was performed. The oligonucleotide was selective for the L. mucosae strains under the conditions used.

\section{DISCUSSION}

The genus Lactobacillus currently includes more than 60 species; three of these were described during 1998 (Morlon-Guyot et al., 1998; Edwards et al., 1998; Bohak et al., 1998) and one was described at the beginning of 1999 (Falsen et al., 1999). Members of this genus have been isolated from a large number of habitats, including oral and genital sites and the gastrointestinal tracts of animals and humans. In pigs, a number of Lactobacillus species have been identified and L. reuteri, L. fermentum, L. acidophilus, $L$. delbrueckii and L. salivarius are commonly reported as being isolated from pig intestine (Stewart, 1997). On two different occasions separated by a 12 -year interval, we have isolated strains of lactobacilli from pig small intestine. Many of these isolates are L. reuteri and one of them, strain 1063, has been characterized with respect to autoaggregation and mucus-binding ability (Roos et al., 1999; S. Roos \& H. Jonsson, unpublished results). Three isolates (1028, 1031 and 1035) were partially described by Axelsson \& Lindgren (1987) and these three strains, together with five new isolates ( 55 , 
$\mathrm{S} 14, \mathrm{~S} 15, \mathrm{~S} 17$ and $\mathrm{S} 32^{\mathrm{T}}$ ), have been further investigated in this work. The common characteristic of these isolates, which originally attracted our attention, was the reactivity with a gene probe derived from the putative colonization-factor gene $m u b$ from $L$. reuteri strain 1063 (S. Roos \& H. Jonsson, unpublished results). When we further examined these isolates we also found that they exhibited in vitro characteristics similar to those of strain 1063, with respect to mucusbinding activity. Primary characterization using sugarfermentation analysis indicated that these isolates were not $L$. reuteri and we therefore used nucleic acid methods to investigate their taxonomic position in more detail. Thus, $16 \mathrm{~S}$ rRNA sequence analysis, $\mathrm{G}+\mathrm{C}$ mol \% determination and DNA-DNA hybridization, together with cell wall analysis, showed that they represent a previously undescribed species. On the basis of phylogenetic analysis, the new species can be allocated to the L. casei-Pediococcus group described by Collins et al. (1991). The closest relatives are $L$. reuteri, L. fermentum and L. pontis, which show $16 \mathrm{~S}$ rRNA sequence similarity values of $95 \cdot 1,94 \cdot 4$ and $94.6 \%$, respectively. The construction of a phylogenetic tree confirmed the close affiliation of the new isolates with the $L$. reuteri-L. fermentum group. DNA-DNA hybridization of total DNA from S32 with the type strains of the three closely related species showed an overall sequence homology in the range $40 \cdot 5-52 \cdot 2 \%$, clearly indicating that L. mucosae constitutes a new species separate from these others. Our own data and also work by others have shown that $L$. reuteri and $L$. mucosae can be found in the same part of the pig intestine. L. fermentum, though frequently reported as being present in the pig intestinal tract, was not found in this niche by Axelsson \& Lindgren (1987). The species L. pontis, L. oris, L. vaginalis and $L$. panis have never been reported as colonizing this environment. However, it must be mentioned that few, if any, ecological studies on the gastrointestinal-tract microbiota have employed $16 \mathrm{~S}$ rDNA sequence determination for identification of the bacteria. The methods that have been used in most studies either fail to detect all types of lactobacilli or fail to distinguish between certain species.

The relationship between $L$. reuteri and L. mucosae is further accentuated by the presence of the $m u b$ gene. Interestingly, the $\mathrm{G}+\mathrm{C}$ content $(\mathrm{mol} \%$ ) of this gene is close to the overall $\mathrm{G}+\mathrm{C}$ content of $L$. mucosae and rather different from that of other genes from $L$. reuteri. Although five of the isolates ( $\mathrm{S} 5, \mathrm{~S} 14, \mathrm{~S} 15, \mathrm{~S} 17$ and $\mathrm{S} 32^{\mathrm{T}}$ ) were primarily selected for harbouring the mub gene, this was not the case with the three previously isolated strains (1028, 1031 and 1035) yet the gene was still present. Thus, it seems that strains of L. mucosae commonly carry this gene. In contrast, the presence of $m u b$ is restricted to a limited number of strains of $L$. reuteri. Altogether, this could implicate $L$. mucosae as the source of $m u b$ and $L$. reuteri as a recipient of the gene at some point during the course of evolution. The presence of a mub homologue in more than one Lactobacillus species and the correlation of the presence of this gene with mucus-binding ability argue that it represents an important part of the colonization mechanism for lactobacilli in the pig intestine.

\section{Description of Lactobacillus mucosae sp. nov.}

Lactobacillus mucosae (mu'co.sae. L. gen. n. mucosae of mucosa).

Cells are Gram-positive, non-motile, non-sporeforming, catalase-negative rods with dimensions of $1 \times 2-4 \mu \mathrm{m}$. The cells occur singly, in pairs or as short chains and have an Orn-D-Asp peptidoglycan type. After anaerobic growth at $37^{\circ} \mathrm{C}$ for $2 \mathrm{~d}$, colonies on MRS agar are $1-2 \mathrm{~mm}$ in diameter. They are white, smooth and convex. The cells are obligately heterofermentative and produce D- and L-lactic acid. They grow at $45^{\circ} \mathrm{C}$ but not at $15^{\circ} \mathrm{C}$. Acid is produced from glucose, ribose, maltose and saccharose. The majority of strains also ferment D-xylose, melibiose, D-raffinose and gluconate. L-Arabinose, galactose or lactose may be utilized by some strains. D-Fructose, glycerol, erythritol, L-xylose, adonitol, D-mannose, L-sorbose, rhamnose, dulcitol, inositol, mannitol, sorbitol, methyl $\alpha$-D-glucoside, $N$-acetylglucosamine, salicine, cellobiose, trehalose, inuline, melizitose, amidon, glycogen, xylitol, D-turanose, D-lyxose, D-taganose, D-fucose, L-fucose, D-arabitol, 2-keto-gluconate and 5-ketogluconate are not utilized. Aesculin is hydrolysed. Arginine is cleaved. The DNA G $+\mathrm{C}$ content of strain $\mathrm{S} 32^{\mathrm{T}}$ is $46 \cdot 5 \pm 0 \cdot 2 \mathrm{~mol} \%$. All strains of this species so far described have a homologue to the mucus-binding protein, Mub, and exhibit mucus-binding ability in vitro.

\section{ACKNOWLEDGEMENTS}

The authors thank Dr Norbert Weiss, DSMZ (Deutsche Sammlung von Mikroorganismen und Zellkulturen, Braunschweig, Germany) for advice regarding phylogeny and nomenclature. This study was supported by grants from The Swedish National Board for Industrial and Technical Development (NUTEK; P5974) in a co-operative project with BioGaia Biologics AB (Stockholm, Sweden).

\section{REFERENCES}

Adlerberth, I., Ahrné, S., Johansson, M.-L., Molin, G., Hanson, L. Å. \& Wold, A. E. (1996). A mannose-specific adherence mechanism in Lactobacillus plantarum conferring binding to the human colonic cell line HT-29. Appl Environ Microbiol 62, 2244-2251.

Axelsson, L. \& Lindgren, S. (1987). Characterization and DNA homology of Lactobacillus strains isolated from pig intestine. J Appl Bacteriol 62, 433-440.

Bohak, I., Back, W., Ehrmann, M., Ludwig, W. \& Schleifer, K. H. (1998). Lactobacillus amylolyticus sp. nov., isolated from beer malt and beer wort. Syst Appl Microbiol 21, 360-364.

Brassart, D. \& Schiffrin, E. J. (1997). The use of probiotics to 
reinforce mucosal defence mechanisms. Trends Food Sci Technol 8, 321-326.

Cashion, P., Holder-Franklin, M. A., McCully, J. \& Franklin, M. (1977). A rapid method for the base ratio determination of bacterial DNA. Anal Biochem 81, 461-466.

Collins, C. H. \& Lyne, P. M. (1970). Microbiological Methods. London: Butterworth.

Collins, M. D., Rodrigues, U., Ash, C., Aguirre, M., Farrow, J. A. E., Martinez-Murcia, A., Phillips, B. A., Williams, A. M. \& Wallbanks, S. (1991). Phylogenetic analysis of the genus Lactobacillus and related lactic acid bacteria as determined by reverse transcriptase sequencing of $16 \mathrm{~S}$ rRNA. FEMS Microbiol Lett 77, 5-12.

De Ley, J., Cattoir, H. \& Reynaerts, A. (1970). The quantitative measurement of DNA hybridization from renaturation rates. Eur J Biochem 12, 133-142.

Edwards, C. G., Haag, K. M., Collins, M. D., Hutson, R. A. \& Huang, Y. C. (1998). Lactobacillus kunkeei sp. nov.: a spoilage organism associated with grape juice fermentations. $J$ Appl Microbiol 84, 698-702.

Elmer, G. W., Surawicz, C. M. \& McFarland, L. V. (1996). Biotherapeutic agents: a neglected modality for the treatment and prevention of selected intestinal and vaginal infections. JAMA ( $\mathrm{J}$ Am Med Assoc) 275, 870-876.

Embley, T. M., Faquir, N., Bossart, W. \& Collins, M. D. (1989). Lactobacilus vaginalis sp. nov. from the human vagina. Int $J$ Syst Bacteriol 39, 116-118.

Escara, J. F. \& Hutton, J. R. (1980). Thermal stability and renaturation of DNA in dimethyl-sulphoxide solutions: acceleration of renaturation rate. Biopolymers 19, 1315-1327.

Falsen, E., Pascual, C., Sjödén, B., Ohlén, M. \& Collins, M. D. (1999). Phenotypic and phylogenetic characterization of a novel Lactobacillus species from human sources: description of Lactobacillus iners sp. nov. Int J Syst Bacteriol 49, 217-221.

Farrow, J. A. E. \& Collins, M. D. (1988). Lactobacillus oris sp. nov. from the human oral cavity. Int J Syst Bacteriol 38, 116-118.

Felsenstein, J. (1993). PHYLIP (Phylogeny Inference Package) version 3.5c. Department of Genetics, University of Washington, Seattle, WA, USA.

Fuller, R. (1989). Probiotics in man and animals. $J$ Appl Bacteriol 66, 365-378.

Granato, D., Perotti, F., Masserey, I., Rouvet, M., Golliard, M., Servin, A. \& Brassart, D. (1999). Cell surface-associated lipoteichoic acid acts as an adhesion factor for attachment of Lactobacillus johnsonii La1 to human enterocyte-like Caco-2 cells. Appl Environ Microbiol 65, 1071-1077.

Gregersen, T. (1978). A rapid method for distinction of Gramnegative from Gram-positive bacteria. Eur J Appl Microbiol Biotechnol 5, 123-127.

Hammes, W. P., Weiss, N. \& Holzapfel, W. (1992). The genera Lactobacillus and Carnobacterium. In The Prokaryotes, 2nd edn, pp. 1535-1594. Edited by A. Balows, H. G. Trüper, M. Dworkin, W. Harder \& K.-H. Schleifer. New York: Springer.

Huis in't Veld, J. H. J., Havenaar, R. \& Marteau, P. (1994). Establishing a scientific basis for probiotic R\&D. Trends Biotechnol 12, 6-8.

Huß, V. A. R., Festl, H. \& Schleifer, K. H. (1983). Studies on the spectrophotometric determination of DNA hybridization from renaturation rates. Syst Appl Microbiol 4, 184-192.

Isolauri, E., Salminen, E. \& Salminen, S. (1998). Lactic acid bacteria and immune modulation. In Lactic Acid Bacteria:
Microbiology and Functional Aspects, 2nd edn, pp. 255-268. Edited by S. Salminen \& A. von Wright. New York: Marcel Dekker.

Jahnke, K.-D. (1992). BASIC computer program for evaluation of spectroscopic DNA renaturation data from GILFORD SYSTEM 2600 spectrophotometer on a PC/XT/AT type personal computer. J Microbiol Methods 15, 61-73.

Kandler, O. \& Weiss, N. (1986). Genus Lactobacillus Beijerinck 1901, 212 AL . In Bergey's Manual of Systematic Bacteriology, vol. 2, pp. 1209-1234. Edited by P. H. A. Sneath, N. S. Mair, M. E. Sharpe \& J. G. Holt. Baltimore: Williams \& Wilkins.

Kotarski, S. F. \& Savage, D. C. (1979). Models for study of the specificity by which indigenous lactobacilli adhere to murine gastric epithelia. Infect Immun 63, 1698-1702.

Lichtenstein, A. H. \& Goldin, B. R. (1998). Lactic acid bacteria and intestinal drug and cholesterol metabolism. In Lactic Acid Bacteria: Microbiology and Functional Aspects, 2nd edn, pp. 269-277. Edited by S. Salminen \& A. von Wright. New York: Marcel Dekker.

Marteau, P. \& Rambaud, J.-C. (1993). Potential of using lactic acid bacteria for therapy and immunomodulation in man. FEMS Microbiol Rev 12, 207-220.

Mesbah, M., Premachandran, U. \& Whitman, W. (1989). Precise measurement of the $\mathrm{G}+\mathrm{C}$ content of deoxyribonucleic acid by high performance liquid chromatography. Int $J$ Syst Bacteriol 39, 159-167.

Morlon-Guyot, J., Guyot, J. P., Bot, B., de Haut, J. \& Raimbault, M. (1998). Lactobacillus manihotivorans sp. nov., a new starchhydrolysing lactic acid bacterium isolated during cassava sour starch fermentation. Int J Syst Bacteriol 48, 1101-1109.

Roos, S., Aleljung, P., Robert, N., Lee, B., Wadström, T., Lindberg, M. \& Jonsson, H. (1996). A collagen binding protein from Lactobacillus reuteri is part of an ABC transporter system? FEMS Microbiol Lett 144, 33-38.

Roos, S., Lindgren, S. \& Jonsson, H. (1999). Autoaggregation of Lactobacillus reuteri is mediated by a putative DEAD-box helicase. Mol Microbiol 32, 427-436.

Salminen, S., Isolauri, E. \& Salminen, E. (1996). Clinical use for probiotics for stabilising the gut mucosal barrier: successful strains and future challenges. Antonie Leeuwenhoek $\mathbf{7 0}$, 347-358.

Sambrook, J., Fritsch, E. F. \& Maniatis, T. (1989). Molecular Cloning: a Laboratory Manual, 2nd edn. Cold Spring Harbor, NY: Cold Spring Harbor Laboratory.

Schleifer, K. H. \& Kandler, O. (1972). Peptidoglycan types of bacterial cell walls and their taxonomic implications. Bacteriol Rev 36, 407-477.

Stewart, C. S. (1997). Microorganisms in hindgut fermentors. In Gastrointestinal Microbiology, vol. 2, pp. 142-186. Edited by R. I. Mackie, B. A. White \& R. E. Isaacson. New York: Chapman \& Hall.

Thompson, J. D., Higgins, D. G. \& Gibson, T. J. (1994). CLUSTAL $\mathrm{W}$ : improving the sensitivity of progressive multiple sequence alignment through sequence weighting, position-specific gap penalties and weight matrix choice. Nucleic Acids Res 22, 4673-4680.

Vogel, R. F., Böcker, G., Stolz, P. \& 7 other authors (1994). Identification of lactobacilli from sourdough and description of Lactobacillus pontis sp. nov. Int J Syst Bacteriol 44, 223-229.

Wadström, T., Anderson, K., Sydow, M., Axelsson, L., Lindgren, S. \& Gullmar, B. (1987). Surface properties of lactobacilli isolated from the small intestine of pigs. J Appl Bacteriol 62, 513-520. 
Weizenegger, M., Neumann, M., Stackebrandt, E., Weiss, N. \& Ludwig, W. (1992). Eubacterium alactolyticum phylogenetically groups with Eubacterium limosum, Acetobacterium woodii and Clostridium barkeri. Syst Appl Microbiol 15, 32-36.

Wiese, B. G., Strohmar, W., Rainey, F. A. \& Diekmann, H. (1996).
Lactobacillus panis sp. nov., from sourdough with a long fermentation period. Int J Syst Bacteriol 46, 449-453.

Yamamoto, K., Miwa, T., Taniguchi, H., Nagano, T., Shimamura, K., Tanaka, T. \& Kumagai, H. (1996). Binding specificity of Lactobacillus to glycolipids. Biochem Biophys Res 228, 148-152. 